\title{
Good Governance Implementation in the Development of Sustainable Tourism; The Portrait of Padang City Government
}

\author{
Eka Siskawati' ${ }^{1}$, Armel Yentifa' ${ }^{2}$, Zahara ${ }^{3}$, Haniva Dela Gusta ${ }^{4}$ \\ ${ }^{1}$ Jurusan Akuntansi, Politeknik Negeri Padang \\ ekasiskawati@gmail.com, \\ ${ }^{2}$ Jurusan Akuntansi, Politeknik Negeri Padang \\ armelyentifa@gmail.com, \\ ${ }^{3}$ Jurusan Akuntansi, Politeknik Negeri Padang \\ zahara.ak@gmail.com, \\ ${ }^{4}$ Jurusan Akuntansi, Politeknik Negeri Padang \\ hanivadela@gmail.com
}

\begin{abstract}
This article describes on how the implementation of good governance is carried out by Padang City Government in sustainable tourism management. This research is aimed to (1) Overseeing the good governance implementation in Padang City Government in term of the development of sustainable tourism destinations. (2) Analyzing the sustainable tourism management viewing it from agency theory. It is a qualitative descriptive research, and performed in Padang City Culture and Tourism Office. More over, data collection utilizes observation, interview, and documentation. The good governance principle employed in this research are accountability, participation, and transparency. The result shows that the implementation of good governance at Padang City Culture and Tourism Office has been achieved well. It is as a result of the agency relationships occured within local government; the relationship with the executive in the role of Culture and Tourism Office, and with public as the community.
\end{abstract}

Kata kunci: Good Governance, Sustainable tourism, Agency Theory

\section{INTRODUCTION}

For the last several years, there has been an increase on interest of domestic and overseas tourist to visit Indonesia. How ever, the high interest of these tourists to visit this country is not in line with the increase on the quality, and environtment activity to conserve the nature. Over the last decade, the tourism sector has been characterized negatively as it damages environment and social community culture of the tourism destination. Recognizing these emerging issues, Indonesian government has implemented sustainable tourism concept to actualize an adequate tourism development referred to local culture, social acceptance, priority on local people, nondiscriminatory, and eco-friendly. Therefore, Indonesian government is sorting out this tourism development by increasing local tourism potential. By having the richness in nature and culture, it can make the tourism potential becoming a significant economic sector in Indonesia. Indeed, Indonesia is one of tourism destinations which has captured the attention of various tourists all over the world (Asmin, n.d.).

According to Presidential Decree No. 57 year 2017, sustainable tourism is a new approach to economic development in tourism sector which has been conducted 
intensely by local governments in Indonesian. In accordance with this decree, the goal of Indonesian development is to meet the government' commitment in achieving the sustainable development goals. It is referred to the government' targets in improving community's welfare, conserving nature, and accelerating the economic development which has been planned to be in realization up to year 2030. This Presidential Decree is in line with Tourism Ministerial Regulation No. 14 Year 2016 on the sustainable tourism guidelines which has been adjusted with the indicators of United Nation World Tourism Organization (UNWTO), and recognized by Global Sustainable Tourism Council (GSTC). Based on the regulation of Minister of Tourism No 14 Year 2016, sustainable tourism is a tourism which considers the impact of economic, social, and environment at recent times and in the future, meets the demand of the visitor' need, industry, environment and local people where it can be applied into all forms of tourism activities in every tourism destinations, including mass tourism and other tourism activities.

In term of the development of sustainable tourism sites, surely it is due in part to the governance system conducted by the local government which is often called as good governance. In implementing a good governance system, government as the main actor of the establishment of this good governance is assured to provide more transparent and accurate responsibility(Aziz, 2009). Acknowledging this governance system, there are three basic elements which are interrelated one to another in implementing good governance, they are: accountability, participation, and transparancy, and employed as the principle of the study. Likewise, in her study concerning on analyzing the management of the village fund carries out the principle of good governance as well consisting of transparancy, participation, and accountability. The result shows that these three principles applied in the village fund management in Tokelan village has been implemented well.

This current research was a qualitative descriptive approach where the object of this research was The Government of Padang Municipality. A case study was conducted in Padang City Culture and Tourism Office due to the tourism potential of this city which kept going up from the year 2015 to 2018 for 405\% (Fachri, 2019). Consequently, the management employed by the local government particularly Culture and Tourism Office in increasing its tourism potential should be questioned based on the escalation of Padang City Own-Source Revenue (PAD). Data collection was carried out through interview, and documentation. Hence, this research was aimed to determine the role of Padang City' Government in managing its tourism destinations.

\section{LITERATURE REVIEW}

\section{GOOD GOVERNANCE}

Good governance is often defined as an approach to goverment that is committed to creating a good system based on an applicable standard. Some experts state that good governance is the process whereby the government conduct public affairs, and manage public resources, while some others consider it as a good government system (Nurastuti, 2018). Furthermore, World Bank defines good governance as the way state power is used in managing economic and social recources for development and society (Mardiasmo, 2004). The term good governance used by World Bank describes the implementation of solid and liable 
development management in line with the principles of democracy and an efficient market, avoidance of mis-allocation on the investment fund, and corruption deterrence with due regard of politics and/ or administrative, the establishment of budgetary discipline, and the creation of legal and political framework on the business growth.

United Nation Development Program (UNDP) determines good governance as the exercise of political, economic, and administrative authority to manage a nation's affair at all levels (Sedarmayanti, 2003). The World Bank stresses more on the way of the government managing social and economic resources in terms of community development, whereas UNDP concentrates more on political, economic, and administrative aspects in state management [5]. Additionally, the meaning of good governance in regards to corporate sector is based on professional ethics in carrying out their business/ corporate affairs. It can be said that it is the form of acceptance on the importance of the regulatory devices or good governance in overseeing relationship, function and interest of various stakeholders in business affairs or public services (Aziz, 2009).

Osborne et al (1991) point out that good governance can be determined as efficient public services, reliable court system, and accountable government to the public. It is in accordance with Nurlaela' (2015) study concluding that good governance is a good governance in managing government and its relationship synergically and constructively between countries, economic and politics performed by abiding the principles of good governance, and is aimed to inaugurate community' welfare.

\section{THE CONCEPT OF GOOD GOVERNANCE}

A governance system is a concept that refers to the process of achieving decision and their implementation involving three stakeholders; state-government, community, and private sector whilst is customarily called as state civil societymarket. Meanwhile the sector which becomes the subject to be administered covering quite comprehensive aspects such as: the use of economic, politics, and administrative authorities in administering state affairs. The subject being managed in the governance system also covers: process, mechanism and institutional, where the citizens and groups of society organize their own needs and overcome their differences. The concept of this good governance is a demand that should be met by public sector. Here, local government is expected to be more responsive or fast (Indriani, n.d).

Sewandono (2016) mentions that one of the significant aspects in good governance, the arrangement regarding to power and the use of authority made by the officials who hold the power should be based on constitution and law; and one of the significant principles of using this power is promoting the limitative and distinctive state power. Governing the authority of power is in regards with the principle development of public participation and accountability. Good governance in the context of sustainable development can be seen as a synergistic efforts integrating the enviroment, human and economic developments. By implementing the principles attached, there is an opportunity for the three factors of sustainable development; government, corporate, and civil society to oversee and participate in the process 
being conducted. Simply put that good governance afterward will be functioned as the element consolidating these three factors into a unity with a common purpose.

Three basic elements which are interrelated to one another in bringing about the good governance are (1) Transparency. It is the openness in the management of government, environment, economic, and social; (2) Participation. It is the implementation of decision-making that represents democracy included the recognizion of Human Rights, the freedom of press, expression and/ or society aspiration; (3) Accountability. It is the responsibility to report and answer from the officials who are the decision-makers to be ultimately accountable of the success or failure in order to reach the satisfaction of the relevant stakeholders, and receive penalty in the absence of satisfaction.

\section{TRANSPARENCY}

National Committee on Governance (2018) points out that transparancy contains the disclosure element, adequate information service which is easily accessed by the stakeholders. This transparency is needed so that supervision conducted by community and corporate onto the government body can be performed objectively. Therefore, this information provision is required through information and documentation systems which are effortlessly obtained regarding to the conceptualization pattern, the content of regulations, and the public policy included their implementation onto each state institution. Nurastuti (2018) also states that this transparancey has to be built in the framework of information freedom from several processes, institutionals, where the information is directly accessible to those concerned with them. This information should be provided sufficiently, and intelligibly so it can be utilized as a monitoring and evaluation tools.

Referring to the criteria of the information provided to support the community participation, Sewandono (2016) explains that the information must be provided in an understandable and accessible format, timeliness, and comprehensiveness of information regarding to government administration. Establishing the mutual trust between the government and the society through the information provision, and ensuring the available information accurately and adequately. The implementation of this transparacy principle is aimed to make the information/ data obtained of the good governance activities including the policy conceptualization and the organization work performance can be accessed by public.

\section{PARTICIPATION}

Participation is the involvement of community who has the right and can utilize it in expressing their opinion, making decision, directly or indirectly through representative agency in delivering their aspiration (Nurastuti, 2018). Participation according to State Administration Agency (LAN), and Financial and Development Supervisory Agency (BPKP) (2000) is every citizen has the right in decision making directly or indirectly through intermediation of legitimate institution in representing their needs. Likewise, (Pertiwi, 2017) stresses that the participation which has been built on the basis of freedom in association and expression including constructively participation. Community' participation can be reviewed from two aspects, the first one is the community' participation in determining the public policy. This can be the 
support in accelerating the fulfillment of accountability principle from government body at village level. The second one is community' participation in budgetting.

Participation in the development process is required by an area. How can an area developed if its community does not participate in conveying their aspiration or providing insight to their region. This community participation is a necessity since it can prevent deviant policies. The direct involvement in the development process is considered as an initial step to lead to the success in the development (Nurastuti, 2018).

\section{ACCOUNTABILITY}

Ratnawati (2006) argues that the accountability can be seen as a supporting factor which can cause pressure on the relevant actors to be responsible on the public service and assurance on public services performance in an efficient manner. Accountability is often put in the same level with responsiblity, and liability. National Committee on Governance (2018) states that accountability contains of the function clarity within an organization and how to make it accountable. This accountability is necessary so that each state institution and government body can perform their tasks responsibly. Thus, each government body should carry out their task fairly, and measured in accordance with laws and regulations, and applicable public policies to avoid the abuse of authority.

Accountability is an obligation to provide and report all related activities, particularly those related to financial administration to the highest party. The media for accountability is not limited only for the report, but also covers convenient aspects to legitimate mandator in the government to receive information, directly or indicrectly, and/ or spoken or written (Sulistiyani, 2005). Increasing the accountability taken by public officials in all sectors related to the needs of wider community. The implementation of Accountability Principle is an obligatory to justify referring to the management and control of resources and policy enforcement including success and failure in achieving its goals and targets being set through accountability media in the form of implementation report (performance accountability) periodically. There are two kinds of accountability, namely (1) Vertical Accountability, which is accountabilty of the fund management to higher authorities, such as accountability of work units to local governments, regional accountability to the central government, and central government to People's Consultative Assembly, and (2) Horizontal Accountability, which is the responsibility that is conveyed to the wider community.

\section{SUSTAINABLE TOURISM}

Tourism is recognized as a system when tourists' enjoyment on the tourist objects and attractions in certain destination takes into account. As a system, tourism consist of elements which are interacted to each other in an organized manner. When tourism characterizes as a journey, tourists will experience and enjoy the tourist objects and attractions with the assistance and service provided by the travel bureau. And when tourism describes as an opportunity in seeking experience, tourists can obtain their satisfaction within their journey by the presence of the professionality of the manager of tourist objects and attractions, and the other way around. (Asmin, 
n.d.) points out that journey and tourism have become an industry with the rapid growth, and main source of income for many developing countries including Indonesia. Indeed, Indonesia has a lot of potential tourist objects and attractions to increase the national income, public welfare, and conservation attempt through ecotourism development.

(Asmin, n.d.) mentions that in principle ecotourism concerns on the natural aspect of tourist objects and attractions, conservation ethics, education, and sustainability. How ever, in reality, mass tourism which has been proven damaging the environment still dominates the tourism development practice in all over areas in Indonesia. Furthermore, serious concerns on lack of utilization and management of this ecotourism destinations exist as regards to the tourism system itself, where the obstacles occured in the product driven, lack of understanding of the market driven, institutional challenges, and lack of support from the government's policy. Responding to these challenges, Indonesian Government applies tourism sustanaible concept to actualize an adequate tourism development based on having its local culture, being recognized socially, prioritizing local people, being indiscriminative and eco-friendly.

\section{RESEARCH METHOD}

This research is a descriptive qualitative research. The object of the research was the Padang City Government. Case study at the Culture and Tourism Office of the Padang city. This studie is motivated by the facts that the tourism is a potential aspect of the Padang city. The economic growth continues to increase from $2015-2018$ by $405 \%$ (Fachri \& Maharani, n.d.). Data for this study is collected through interviews, observation and documentation.

\section{DISCUSSION}

\section{TOURISM AND REGIONAL ECONOMIC'S GROWTH}

Padang as the province capital city has a huge potential as the center of development growth in West Sumatera. The economic' growth surely will increase the society' welfare and dignity of life. Literally, Padang City development focus has been planned well by considering factors of the development success. Consequently, the regional government at recent times just has to actualize the plannings which have been set previously. The stages of tourism destination improvement consists of planning, budgetary, actualization, and reporting, whilst the implementation process will be conducted gradually.

At present, the government of Padang City concentrates on the industrial development in terms of service sectors such as tourism, trade, and education. The first rationale is seeing from its geographical location. Padang City is located on the western part of the province where the access for goods distribution is extremely demanding due to the establishment of manufacturing industry. The second rationale is as the province capital, Padang City has a good quality schools which get the public's interest. Undoubtedly, most people in this city choose the best higher institutions to continue their study. The third rationale is overseeing the origin and the nature of Minangkabau people with their characteristic as merchandiser. Accordingly, the advancement in terms of tourism, trade, and education becoming the 
pillars of economic' development in this city. Certainly, since the focus set by this city involving these three sectors, tourism industry has become one of priorities put as the primary key for the future development for the city. It is as a result of the more enthusiasts come for tourism visit to Padang City, the higher the impact to the economic development like hotels, restaurants, small traders, and other aspects around the tourism destination areas. Along these lines, the efforts made for tourism improvement are taken into account to attract more visitors to these tourism destinations in this city. Significantly, the increase on tourism development will also raise Local-Own-Source Revenue (PAD) of Padang City.

As a matter of fact, the efforts that have been made by local government in increasing its PAD are challenging as the tourism development cannot be carried out simultaneously. In other words, this tourism development will be conducted gradually so the maximum achievement can be reached. Therefore the reformation made in this city is depended upon the tourism sector set, taken as example is the effort made by the government in restructuring Purus Coast area. Initially, this restructuring is performed onto the merchants who build their stalls along the coast. All this time, their stalls have been overshadowed the beauty of this coast from the visitors' interest, and unfortunately their presences decrease the value of this coast. Considering this, the local government makes the change by relocating these stalls to accross the street, and it results a clear view along the coast where its beauty can be consummated by the visitors. Hence, this coast receives more visitors during the Eid al Fithr ( religious holiday celebrated by Muslim worldwide), New Year, and School Holidays. This achievement can be attained as this development involves many parties like related stakeholders and Local Government Work Agency (OPD).

\section{VISION AND MISSION OF THE MAYOR AS SUSTAINABLE TERM OF REFERENCE}

Culture and Tourism Office is a government body formulating and implementation of public service relating to the culture and tourism sector based on its major task and function performing regional government's work. Elected Padang City Mayor and Vice Mayor year 2019-2024 state in public their vision and mission during their time holding the power to focus on the development and advancement in tourism, trade, and education sectors. This vision and mission illustrates the superior tourism which will be established in Padang City by Culture and Tourism Office in line with the appointed programs. One of Mayor of Padang City' visions and missions is "Improving the quality of tourism management which are safe and profound", and it has become the vision and mission of Culture and Tourism Office as well.

Within the government body of this Culture and Tourism Office is included Bureau of Program and Planning which is responsible in the implementation of Work Plan and Budget. This bureau then elaborates the sustainable tourism programs into the budgetary plan. It is expected that the implementation of this program can achieve the tourism quality target which are safe, comfortable, and profound. After conducting the program planning, this bureau will design budget proposal which will be budget details. Based on this planned budget, the concern of the local government is on the advancement of Gunung Padang Integrated Tourism Region (KWT) consisting of five locations; Gunung Padang, Air Manis Coast, Padang Coast, Old Town, and Muara Harbor. 
Adding the tourism destinations to the eastern area is preceded with the development conducted in Gunung Padang KWT. Over time, government of Padang City realizes the impact caused by this tourism industry with the presence of multiplier effect. Multiplier effect refers to the multiplication of each national income post arising from any injections occured when tourism industry flourished, thus hotels, culinary, and souvenirs industry are going to be expanded as well whereby it becomes one of the aspects in increasing public welfare. Afterward, the impact resulted from this multiplier effect is applied by Culture and Tourism Office into its activities, starting from the well-designed tourism planning of Padang City within five areas of advancement mentioned previously. Nonetheless, the centralization of local government' tourism development is only done onto two or three areas because of all the programs set by the mayor, the implementation occurs in different time. The sustainable tourism program is a project that is instructed by the Ministry of Tourism as stated in Ministerial of Tourism' Regulation No. 14 year 2016. How ever, this regulation has not taken as the major refence by the local government. It can be said that the tourism development of Padang City is a framework constituted in the vision and mission of the mayor within the Law No. 10 year 2009. Hence, concerning sustainable tourism program, there is a hierarchy should be acknowledged in implementing the programs.

\section{CONCLUSION}

Transparency or openness in the implementation of sustainable tourism development performed by Padang City Culture and Tourism Office is with regard to the transparency on the implementation of public policies. In this matter, the term of reference used by this office is derived from Mayor of Padang City' vision and mission. In the planning process of tourism development in this city, the local government involves the community in the decision-making stage, where public has the right to participate in expressing their opinion besides government itself.

This city Culture and Tourism office publicizes their activities and work implementation through printed and electronic mass media, and social media such as instagram; @pariwisata.padang. Meanwhile for the department's policy, it can be accessed through its website; http://pariwisata.padang.go.id/, and the news about tourism is through newspapers and television channels. Besides that this office also provides tourism information about this city in the form of hardcopy like booklet, leaflet, and pocket book containing tourism promotions, significant information regarding to tourism, places to go for culinary, and regulations in tourism destinations. Another means in obtaining information is through call center for visitors to file a complaint on each tourism destination that they visit.

Financial statement and work performance reports are prepared by this office, and then publicized as the form of government transparency on information. This publication is carried out by the Mayor in the Regional Communication Forum (Forkomimda) addressed to public who are resided in Regional People's Representative Assembly (DPRD). The parties which are involved in this Forkomimda, namely Indonesian National Police and Army, Judiciary, Society, and Journalists. Journalists play a significant role in actualizing the transparent government, therefore the transparency principle taken by this this office has been performed since there is a flow of information from the process conducted. Besides 
that the information is freely available and directly accessible to the public who are affected by the decision, and it is provided satisfactorily and intelligibly so it can be used as a mean of monitoring and evaluation.

Public participation in good governance implementation refers to how civil society takes part and participates in good governance implementation itself. The implementation of sustainable tourism program by the regional office of Culture and Tourism involves all parties registered in Penta Helix; Government, Business, Community, Academics, and Media. The involvement of related parties in implementing sustainable tourism begins with the planning process of the tourism program, budgeting, actualization to reporting. This public participation is overseen not only from Penta Helix elements, but also from two aspect, the first one is the determination of public policies, and the second one is on budgeting. Public is also advised to be more proactive and interactive participating in Community Consultations on Development Planning (Musrembang).

The compliance on accountability principle of this Culture and Tourism Office can be seen from its liability in implementating the process of tourism management from planning, then continues to budgeting, implementation, and the presence of reporting. This reporting is performed by this office in terms of financial statement and work performance report. The financial statement consists of Report on Local Government Finances (LKPD), and Public Accountability Report (LKPJ), whereas for work performance report consists of Government Agency Performance Accountability System (SAKIP), and Government Agency Performance Accountability Report (LAKIP) which are handed to DPRD, and announced by the Mayor within the Forkomimda. This office has been working in accordance with the local regulation or mayor' regulation. Local Development Planning Agency (Bappeda) administers assistance to the Mayor in planning the region development through Regional Secretary (Sekda) in establishing General Budget Policies-Provisional Budget Priorities and Funding Levels (KUA-PPAS) which becomes the basis in carrying out the tourism development activities.

\section{REFERENCE}

Asmin, F. (n.d.). Ekowisata dan Pembangunan Berkelanjutan: Dimulai dari Konsep Sederhana.

Https://Www.Google.Com/Url? $S a=t \& r c t=j \& q=\& e s r c=s \&$ source $=$ web $\& c d=1 \& c a d=$ rja\&uact $=8 \&$ ved $=2$ ahUKEwiUzKy80YXmAhW8xzgGHXyoB3MQFjAAegQIBhAB\&u $r l=h t t p s \% 3 A \% 2 F \% 2 F w w w . R e s e a r c h g a t e . N e t \% 2 F p u b l i c a t i o n \% 2 F 323309174 \_E k o w i$ sata_dan_Pembangunan_Berkelanjutan_Dimulai_dari_Konsep_S.

Aziz, A. A. (2009). The Relationship between Energy consumption, Energy Prices and Economic Growth in Malaysia. (2001), 2009.

Fachri, F., \& Maharani, E. (n.d.). Kota Padang Terus Gali Potensi Wisata. Https://Www.Republika.Co.Id/Berita/Nasional/Daerah/19/03/15/Poe25m335-KotaPadang-Terus-Gali-Potensi-Wisata.

Mardiasmo. (2004). Akuntansi Sektor Publik. Yogyakarta: Andi Offset.

Nurastuti, M. (2018). Analisis Penerapan Prinsip Partisipasi, Transparansi, dan Akuntabilitas dalam Pengelolaan Dana Desa (Studi Kasus pada Desa Tokelan, 
Kecamatan Panji, Kabupaten Situbondo). Tugas Akhir Universitas Jember.

Pertiwi, S. H. D. (2017). Analisis Implementasi Prinsip - Prinsip Good Governance pada Pemerintahan Desa Nepo Kecamatan Tanasitodo Kabupaten Wajo. Tugas Akhir Universitas Hasanuddin Makasar.

Sedarmayanti. (2003). Good Governance (Kepemerintahan yang Baik). Bandung: Mandar Maju.

Sulistiyani, A. T. (2005). Memahami Good Governance dalam Perspektif Sumber Daya Manusia. Yogyakarta: Gaya Media. 